\title{
Dynamic Analysis of a Drillstring-Riser System Drilling in Deep Water
}

\author{
Maolin Liao*, Yingcao Zhou, Yinao Su, Zhilong Lian, Hongwei Jiang \\ CNPC Drilling Research Institute, Beijing, China, 102206
}

\begin{abstract}
A mathematical model of a drillstring-riser system is developed to analyze the system dynamics when drilling in deep water. For the proposed model, a riser and a drillstring are combined as a pipe-in-pipe structure, along which the interactions between the riser and the drillstring are introduced by a series of spring-friction units. Numerical simulations of the developed mathematical model are carried out by Abaqus in which the finite element method is adopted. Comparing with the riser deflection calculated by previously published models which exclude the influences of the drillstring-riser interactions, the maximal riser deflection obtained by using the proposed drillstring-riser system is relatively small. Namely, the drillstringriser interactions restrict the riser deflection. This finding indicates that, in a given safety margin of the riser deflection, the drillstring-riser system has stronger capacity of anti-deflection. Additionally, the influence of sea depth is investigated; the dynamic response of a drillstring-riser system drilling in deep water is obviously different from the corresponding condition drilling in shallow water. In order to maintain the drillstring-riser system work in a safe condition, the operations, such as thickening the riser wall, enhancing the control of the top drift, removing a part of buoyancy modules, decreasing WOB, and increasing the top tension of the riser, are suggested to be applied.
\end{abstract}

\section{Introduction}

The main difference of offshore drilling from onshore drilling is that drilling rigs and drilling fluids reach the wellhead through a riser system whose length is the same as the sea depth [1]. The top side of a riser system is connected with a drilling platform or a drilling vessel, and the bottom side of a riser system joins with a blowout preventer (BOP) which is installed on the wellhead [2]. A drillstring system rotates inside the riser system. Under the effects of the ocean loads, the drillstring-riser system deflects, and the corresponding contact and friction occur intermittently along the whole pipe-in-pipe structure.

The investigations of the riser dynamics can be traced back to 1970s. Burke built up the static and dynamic models of a riser system for $800 \mathrm{ft}$ sea depth [3]. Simmonds used the finite difference method to solve Burke's differential equations, and analyzed the distribution of riser deflection [4]. Still based on Burke's model, Krolikowski and Gay applied an improved linearization technique to analyze the frequency domain of a riser system [5]. Dareing and Huang discussed the variations of the natural frequencies for the low order modes of a riser system as adjusting system parameters [6]. Kirk et al. analyzed the influences of top tension on the variation of frequency domain when the riser system was subjected to periodic excitation. They also provided the bending moment distribution of a riser system under different order resonances [7]. Patel and Sarohia applied the finite element method to analyze riser dynamics. In their work, the ocean loads were set as regular, and the hydrodynamic damping was linearized [8]. Bueno and Morooka designed an interaction model to calculate the drillstring-riser contact force [9]. Yazdchi and Crisfeld applied the Reissner-Simo beam rather than the EulerBernoulli beam to consider the hydrodynamic effect on the shear deformation of a riser system [10]. Nair and Baddour divided a riser system into pieces which were connected by a series of spring-damper units [11]. Chen et al. analyzed the design factors of a riser system [12]. Wang et al. did the coupled dynamic analysis of a riser system under combined forcing and parametric excitation [13]. Meanwhile, aiming at the minimum variance of the bottom flexible joint deflection angle, they optimized the top tension of the riser system [14]. Based on the theoretical and experimental studies, Zhou et al. found 'one third effect' for a riser system drilling in deep water. Specifically, when a riser system works in shear flows, its maximal deflection is explored around $1 / 3$ sea depth [15]. Liu et al. developed an experimental system for testing the riser system working in deep water, their system was designed based on the system parameters of the 6th generation deep water drilling platform, HYSY-981 [16].

Summarily, the previous investigations mainly focused on the dynamic analysis of the riser system. Both Reissner-Simo beam and Euler-Bernoulli beam were used for developing the mathematical models. Morrison equations were applied to describe the loads caused by sea wave and sea current. Several models considered the influences of the flow of drilling fluid, and a few models

\footnotetext{
* Corresponding author: liaomldr@cnpc.com.cn
} 
discussed the effects of the drillstring vibrations. The developed models were solved by finite difference methods or finite element methods. Both time domain analysis and frequency domain analysis were carried out. The influences of the system parameters, such as top tension, water depth, platform drift, and buoyancy factor, etc., on the riser dynamics were analyzed. According to the literature review, a dynamic model about the drillstring-riser system which takes the drillstring-riser interactions into consideration needs to be developed, and a detailed dynamic analysis of the developed model should be carried out, both of which are benefit for feasibility and safety of offshore drilling in complicated deep water.

This paper is organized as follows. Section 2 introduces the mathematical modeling of a drillstring-riser system. Section 3 conducts the numerical simulation of the developed mathematical model using finite element method in Abaqus. In Section 4, the parameter sensitivity is analyzed. The influences of sea depth and design parameters on the dynamic responses of a drillstring-riser system are analyzed successively. Concluding remarks are provided in Section 5.

\section{Mathematical modeling of a drillstring- riser system}

The dynamic model of a drillstring-riser system consists of a pipe-in-pipe deformation model (see Fig.1 (a)) and a drillstring-riser interaction model (see Fig.1 (b)). The pipe-in-pipe structure deforms under the effects of the ocean loads from its outside. The interaction model describes the contact force and friction between a drillstring and a riser along the pipe-in-pipe structure. Two independent coordinate systems are set to describe the riser system (xyz) and the drillstring system (x'y'z'), respectively. The correlations between the two coordinate systems connect the two models together to form a complete dynamic model for the investigated drillstring-riser system. (a)

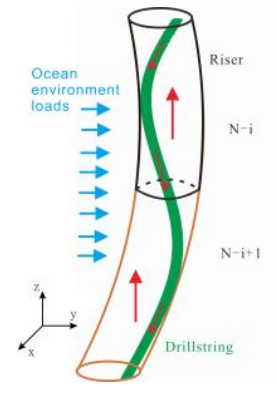

(b)

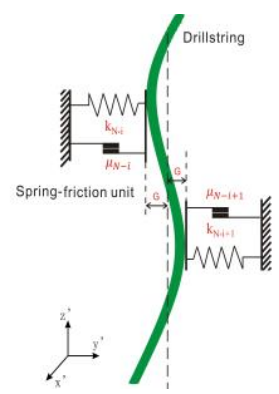

Fig. 1. (a) Pipe-in-pipe deformation model and (b) drillstringriser interaction model.

Primarily, to describe the ocean loads around the pipein-pipe deformation model, Ekman drift theory [2] is adopted to calculate the flow velocity of sea current as

$$
u_{C}= \begin{cases}K_{w} v_{m}\left(z-L+H_{c}\right) / H_{c}+v_{t}(\mathrm{z} / L)^{1 / 7} & \left(\mathrm{~L} \leq H_{c}\right) \\ v_{t}(\mathrm{z} / L)^{1 / 7} & \left(\mathrm{~L}>H_{c}\right)\end{cases}
$$

where the friction depth is calculated as

$$
H_{c}=\frac{7.6 v_{19}}{\sqrt{\sin \varphi}}
$$

Airy wave theory [2] is applied to calculate the velocity and the acceleration of sea wave, which are listed in Eq.3 and Eq.4, respectively.

$$
\begin{aligned}
& u_{W}=\pi h_{W} / T_{W} e^{2 \pi(z-L) / L_{w}} \cos (\omega t) \\
& a_{W}=2 \pi^{2} h_{W} / T_{W}{ }^{2} e^{2 \pi(z-L) / L_{w}} \sin (\omega t)
\end{aligned}
$$

According to the obtained parameters of sea wave and sea current, Morison equation is used to calculate the drag force and the inertial force caused by the ocean loads [3]. Meanwhile, considering the shear force, tension, gravity, and inertia force of a riser system, the differential equation about the dynamic behavior of a riser system can be described as Eq.5 as

$$
\begin{aligned}
& \frac{\partial^{2}}{\partial z^{2}}\left[E I(z) \frac{\partial^{2} y}{\partial z^{2}}\right]+P(z) \frac{\partial^{2} y}{\partial z^{2}}+\left(1-B_{f}\right) m(z) g \frac{\partial y}{\partial z}+m(z) \frac{\partial^{2} y}{\partial t^{2}}+ \\
& \frac{1}{2} C_{d} D \rho\left(u_{w}+u_{c}-\frac{\partial y}{\partial t}\right)\left|u_{w}+u_{c}-\frac{\partial y}{\partial t}\right|+ \\
& \frac{1}{4} D^{2} \pi \rho\left[C_{m} a_{w}-\left(C_{m}-1\right) \frac{\partial^{2} y}{\partial t^{2}}\right]=0
\end{aligned}
$$

In order to further introduce the effects of the drillstringriser interactions into the mathematical model, a series of spring-friction units are set along the pipe-in-pipe structure in the physical model. A Heaviside function, $\mathrm{H}\left(y-y^{\prime}-G\right)$, is considered to check whether the drillstring-riser interaction happens at certain position.

$$
\mathrm{H}\left(y-y^{\prime}-G\right)= \begin{cases}0 & \left(y-y^{\prime}<G\right) \\ 1 & \left(y-y^{\prime} \geq G\right)\end{cases}
$$

When $y-y^{\prime} \geq G$, the drillstring-riser interaction happens; hence the contact force and friction are triggered, and the corresponding calculation equation is shown in Eq.7.

$$
F_{g-y}=K(z)\left(y-y^{\prime}-G\right)+\mu(z) K(z)\left(y-y^{\prime}-G\right)
$$

Based on Eq.5 and Eq.7, the differential equation about the dynamic behavior of a riser system can be described as Eq.8 as

$\mathrm{H}\left(y-y^{\prime}-G\right)\left[K(z)\left(y^{\prime}-y-G\right)+\mu(z) K(z)\left(y^{\prime}-y-G\right)\right]+$ $\frac{\partial^{2}}{\partial z^{2}}\left[E I(z) \frac{\partial^{2} y}{\partial z^{2}}\right]+P(z) \frac{\partial^{2} y}{\partial z^{2}}+\left(1-B_{f}\right) m(z) g \frac{\partial y}{\partial z}+m(z) \frac{\partial^{2} y}{\partial t^{2}}+$

$\frac{1}{2} C_{d} D \rho\left(u_{w}+u_{c}-\frac{\partial y}{\partial t}\right)\left|u_{w}+u_{c}-\frac{\partial y}{\partial t}\right|+$

$\frac{1}{4} D^{2} \pi \rho\left[C_{m} a_{1 W}-\left(C_{m}-1\right) \frac{\partial^{2} y}{\partial t^{2}}\right]=0$

The boundary conditions and the initial conditions for the riser system can be described as Eq.9 and Eq.10, respectively.

$$
y(0, t)=0 ; \quad E I(0) \frac{\partial^{2} y(0, t)}{\partial z^{2}}=k_{b} \frac{\partial y(0, t)}{\partial z} ;
$$




$$
\begin{gathered}
y(L, t)=S(t) ; \quad E I(L) \frac{\partial^{2} y(L, t)}{\partial z^{2}}=k_{t} \frac{\partial y(L, t)}{\partial z} \\
y(z, 0)=0 ; \frac{\partial y(z, 0)}{\partial t}=0
\end{gathered}
$$

Similar to Eq.8, the corresponding differential equation about the dynamic behavior of the drillstring system can be expressed as Eq.11 as

$$
\begin{aligned}
& \mathrm{H}\left(y-y^{\prime}-G\right)\left[K(z)\left(y^{\prime}-y-G\right)+\mu(z) K(z)\left(y^{\prime}-y-G\right)\right]+ \\
& \frac{\partial^{2}}{\partial z^{\prime 2}}\left[E I^{\prime}\left(z^{\prime \prime}\right) \frac{\partial^{2} y^{\prime}}{\partial z^{2}}\right]+P^{\prime}\left(z^{\prime}\right) \frac{\partial^{2} y y^{\prime}}{\partial z^{\prime}}+m^{\prime}\left(z^{\prime}\right) \frac{\partial y^{y}}{\partial z}+m^{\prime}\left(z^{\prime}\right) \frac{\partial^{2} y^{y}}{\partial t^{2}}=0
\end{aligned}
$$

The boundary conditions and the initial conditions of the drillstring system can be described as Eq.12 and Eq.13, respectively.

$$
\begin{aligned}
& y^{\prime}(0, t)=A \sin (\Omega t) ; \frac{\partial y r(0, t)}{\partial z}=0 ; \\
& y^{\prime}(L, t)=S(t) ; \quad \frac{\partial y r(L, t)}{\partial z}=0 \\
& y^{\prime}\left(z^{\prime}, 0\right)=0 ; \frac{\partial y r(z, 0)}{\partial t}=0
\end{aligned}
$$

\section{Numerical simulation of a drillstring- riser system}

Due to the introduction of the drillstring-riser interactions in the proposed mathematical model, repeated iterations are needed to confirm the impact positions, and the iterations increase the calculation complexity, hence decrease the calculation efficiency. Under such circumstances, the finite element analysis software, Abaqus, was considered to carry out numerical simulation. Since, in Abaqus, a number of interaction models are available to simulate a variety of interactions, such as contact, friction, etc.

To build the corresponding finite element model of the proposed mathematical model in Abaqus, the Timoshenko beam element, B31, was chosen to construct both the riser system and the drillstring system. The edge-to-edge contact model which belongs to the general-contact module was adopted to simulate the drillstring-riser interactions. Since the riser system connects with the drilling platform at its top side by an upper flexible joint and connects with the BOP at its bottom side with a lower flexible joint. The connector element, CONN3D2 which includes a joint-rotation combination, was used to describe the upper and lower flexible joints. Additionally, the ocean loads were set by the Aqua module. Aqua calculates ocean loads based on Morison equation which agrees with the method applied in the mathematical model. After the completion of the finite element model, the dynamic analysis was carried out. According to Ekman drift theory, the current velocity was set to be decreased exponentially from $1.35 \mathrm{~m} / \mathrm{s}$ to $0 \mathrm{~m} / \mathrm{s}$ from the sea level to the mud line. Additionally, in order to exclude the disturbances of transient dynamic behaviors, the simulation duration was set as 100 periods of sea wave, and only the last 20 periods were chosen for the analyses of dynamic responses, to secure the simulated system reaches its dynamic stable state.

The simulation parameters about drillstring, riser, and fluids are listed in Table.1. The result of a numerical simulation case is shown in Fig.2. In subplot (a), the drillstring-riser system in its dynamic stable state is displayed, where the system lateral deflection is enlarged 10 times. The red part, which locates around 1/3 sea depth, marks the maximal deflection. Subplot (b) shows the drillstring-riser interaction, the inner pipe represents the drillstring and the outer pipe represents the riser. The red curve, which is the central line of the pipe-in-pipe structure, is applied to observe the dynamic response of this structure in real-time. Subplot (c) compares the riser deflection distributions between a riser system and a drillstring-riser system, in which, the drillstring-riser

\begin{tabular}{|c|c|c|c|c|c|c|c|c|}
\hline \multirow[t]{2}{*}{ drillstring } & $\begin{array}{l}\text { material } \\
\text { density } \\
\left(\mathrm{kg} / \mathrm{m}^{2}\right)\end{array}$ & $\begin{array}{l}\text { elastic } \\
\text { modulus } \\
(\mathrm{GPa})\end{array}$ & $\begin{array}{l}\text { external } \\
\text { diameter } \\
\quad(\mathrm{m})\end{array}$ & $\begin{array}{c}\text { thickness } \\
\text { (m) }\end{array}$ & $\begin{array}{l}\text { top } \\
\text { tension } \\
\text { ratio }\end{array}$ & $\begin{array}{l}\text { contact } \\
\text { stiffness } \\
(\mathrm{kN} / \mathrm{m})\end{array}$ & $\begin{array}{l}\text { friction } \\
\text { coefficient }\end{array}$ & $\begin{array}{l}\text { amplitude } \\
\text { of drillbit } \\
\text { (m) }\end{array}$ \\
\hline & 7850 & 210 & 0.1492 & 0.00917 & 1.0 & 18000 & 0.05 & 0.02 \\
\hline \multirow[t]{2}{*}{ riser } & $\begin{array}{c}\text { material } \\
\text { density } \\
\left(\mathrm{kg} / \mathrm{m}^{2}\right)\end{array}$ & $\begin{array}{l}\text { elastic } \\
\text { modulus } \\
(\mathrm{GPa})\end{array}$ & $\begin{array}{l}\text { external } \\
\text { diameter } \\
\text { (m) }\end{array}$ & $\begin{array}{l}\text { thickness } \\
\text { (m) }\end{array}$ & $\begin{array}{l}\text { stiffness of } \\
\text { upper joint } \\
(\mathbb{N}-\mathrm{m} / \mathrm{rad})\end{array}$ & $\begin{array}{l}\text { stiffness of } \\
\text { lower joint } \\
(\mathrm{N}-\mathrm{m} / \mathrm{rad})\end{array}$ & $\begin{array}{l}\text { top } \\
\text { tension } \\
\text { ratio }\end{array}$ & $\begin{array}{l}\text { buoyancy } \\
\text { factor }\end{array}$ \\
\hline & 7850 & 210 & 0.5334 & 0.0191 & 5000000 & 7300000 & 1.2 & 0.9 \\
\hline \multirow[t]{2}{*}{ fluids } & $\begin{array}{c}\text { seawater } \\
\text { density } \\
\left(\mathrm{kg} / \mathrm{m}^{2}\right)\end{array}$ & $\begin{array}{c}\text { drag } \\
\text { coefficient }\end{array}$ & $\begin{array}{c}\text { inertial } \\
\text { coefficient }\end{array}$ & $\begin{array}{l}\text { sea wave } \\
\text { amplitude } \\
\text { (m) }\end{array}$ & $\begin{array}{l}\text { sea wave } \\
\text { period } \\
(\mathrm{s})\end{array}$ & $\begin{array}{l}\text { wind } \\
\text { speed } \\
(\mathrm{m} / \mathrm{s})\end{array}$ & $\begin{array}{c}\text { factor of } \\
\text { wind speed }\end{array}$ & $\begin{array}{c}\text { density of } \\
\text { drilling fluid } \\
\left(\mathrm{kg} / \mathrm{m}^{2}\right)\end{array}$ \\
\hline & 1050 & 0.7 & 2.0 & 3.0 & 9.0 & 5.0 & 0.03 & 1200 \\
\hline
\end{tabular}
interaction is demonstrated to be significant for restricting the riser deflection. Therefore, to precisely simulate the dynamic responses of a deep water drilling system, it is necessary to take the drillstring-riser interactions into considerations.

Table 1. List of simulation parameters 
(a)

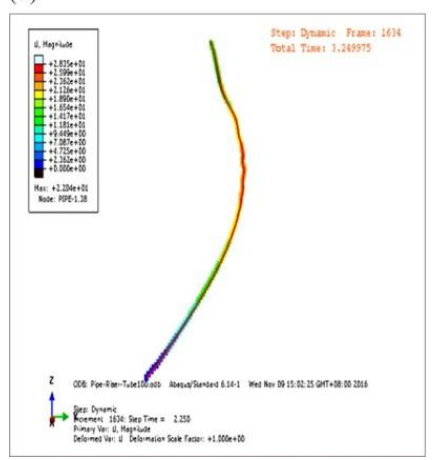

(b)

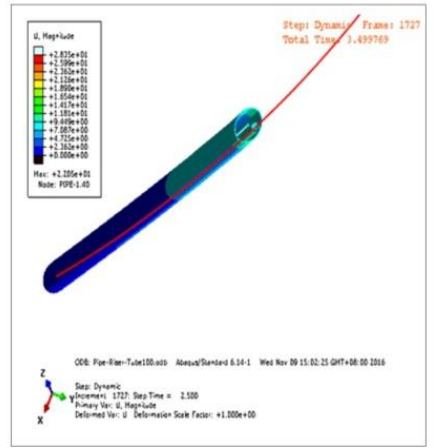

(c)

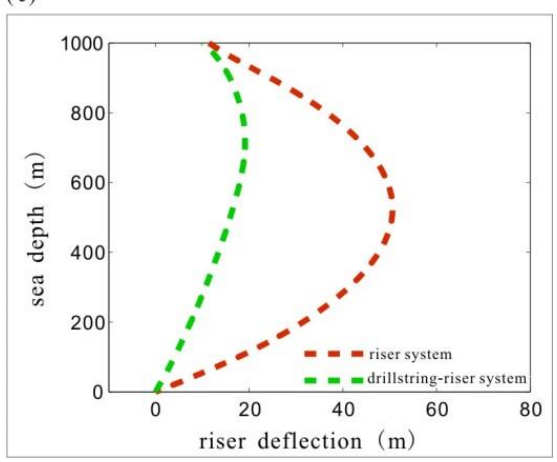

Fig.2. Numerical simulation using Abaqus. (a) Dynamic stable state of a drillstring-riser system, (b) the drillstring-riser interaction, and (c) comparison of the riser deflection distributions between a riser system and a drillstring-riser system

\section{Parameter sensitivity analysis}

The numerical simulation conducted in Section 3 demonstrates the feasibility of dynamic analysis of a drillstring-riser system by using Abaqus. Therefore, in this section, a series of parameter sensitivity analyses of the drillstring-riser system will be carried out based on the developed finite element model in Section 3.

\subsection{Influences of sea depth}

The dynamic response of a drillstring-riser system submerged in deep water is expected to be different from that submerged in shallow water. In order to fully understand the influences of sea depth, numerical simulations for three different sea depths, $200 \mathrm{~m}, 1000 \mathrm{~m}$, and $2000 \mathrm{~m}$ were conducted, the simulation results are shown in Fig.3. Specifically, Subplots (a), (b), (c) show the distributions of the riser deflection, riser bending moment, and riser Mises stress, respectively. Subplots (d), (e), (f) show the distributions of the drillstring deflection, drillstring bending moment, and drillstring Mises stress, respectively. Subplots (g), (h), (i) show the rotation angle distribution of the riser system, and the time histories of the upper and low flexible joints, respectively.

In subplots (a) and (d), the deflections of the riser and the drillstring are similar; both of their maximal deflections locate around $1 / 3$ sea depth. The maximal deflection increases as the increase of sea depth; however, the ratio between the maximal deflection and the sea depth decreases as the increase of sea depth. Comparing subplots (b) and (e), the bending moment of the riser is much larger than that of the drillstring; since strong ocean loads act on the riser. As shown in subplot (b), in the shallow water $(200 \mathrm{~m})$, the bending moment varies considerably along the whole riser; however, as the sea depth increases to $1000 \mathrm{~m}$ or $2000 \mathrm{~m}$, the large bending moments are observed only within the top $10 \%$ sea area. This is because the ocean loads attenuate exponentially as the increase of sea depth. In addition, the maximal bending moment decreases as the increase of sea depth. This is because the riser length extends as the water depth, and a stronger gravity helps the riser keep vertical. Similar to the bending moment, in deep water, the large Mises stress of the riser also concentrates on the top $10 \%$ sea area, see subplot (c); since its Mises stress is mainly determined by the high bending stress. As a comparison, for the drillstring working inside the riser, its bending moment is small, and its Mises stress is mainly determined by tension stress; hence its Mises stress distributes approximately linearly, see subplot (f).

As shown in subplot $(\mathrm{g})$, the rotation angle of the riser varies nonlinearly from its top to bottom. In subplot (h), the rotation angle of the upper flexible joint shows periodic fluctuation which agrees with the periodic motion of sea wave. In subplot (i), the periodic fluctuation of the rotation angle of the lower flexible joint is only observed for the shallow water case $(200 \mathrm{~m})$. As the sea depth increases to $1000 \mathrm{~m}$ or $2000 \mathrm{~m}$, the influences of ocean loads on the lower flexible joint become weak; hence, the rotation angle of the lower flexible joint remains dynamic stable state.

\subsection{Influences of design parameters}

The influences of sea depth have been demonstrated to be significant; however, it is a precondition rather than a design parameter which can be controlled or adjusted. According to the developed dynamic model, the design parameters for a drillstring-riser system mainly include riser thickness, top drift, buoyancy factor, weight on bit (WOB), and top tension of riser.

In order to analyze the parameter sensitivity, a standard study case with $2000 \mathrm{~m}$ sea depth was simulated primarily, and then the design parameters were modified successively to compare with the dynamic responses of the standard case. All the simulation results are displayed in Fig.4. Specifically, Subplots (a), (b), (c) show the distributions of the riser deflection, riser bending moment, and riser Mises stress, respectively. Subplots (d), (e), (f) show the distributions of the drillstring deflection, drillstring bending moment, and drillstring Mises stress, respectively. Subplots (g), (h), (i) show the rotation angle distribution of the riser system, and the time histories of the upper and low flexible joints, respectively.

According to the comparisons in Fig.4, all the investigated design parameters are proved to be able to 


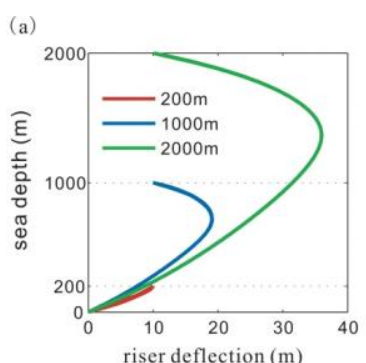

(d)
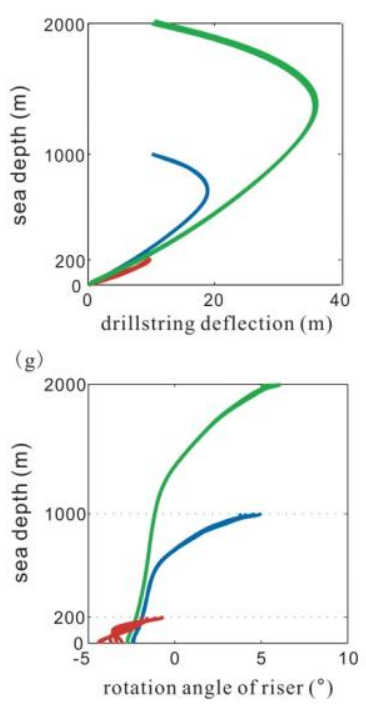

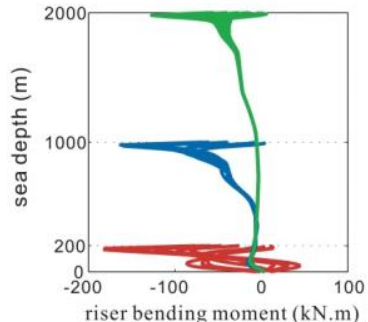

(e)
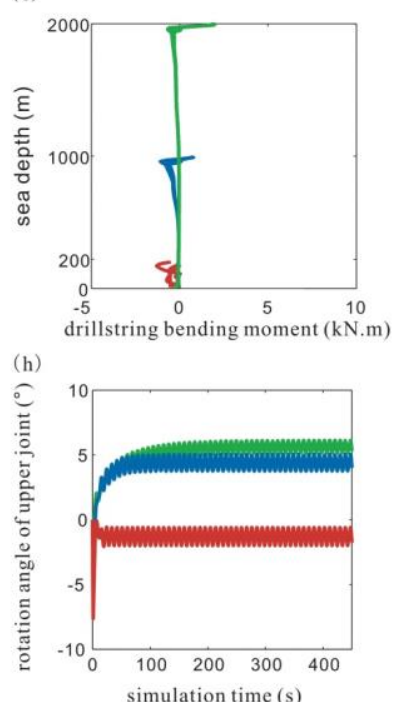

(c)

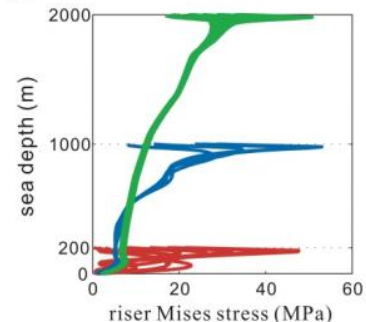

(f)
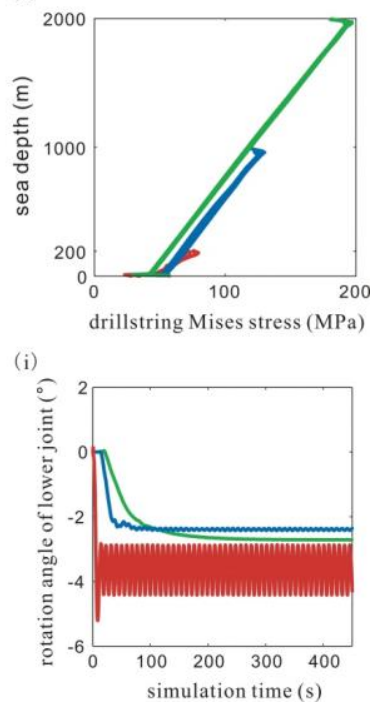

Fig.3. Comparison of dynamic responses of drillstring-riser systems working in different sea depths.

(a)

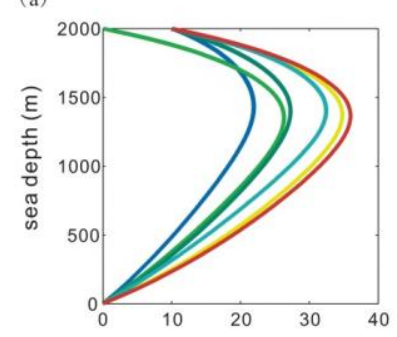

(d)

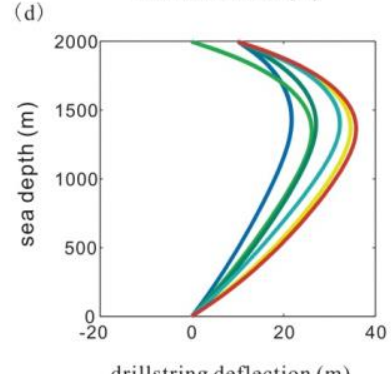

(g)

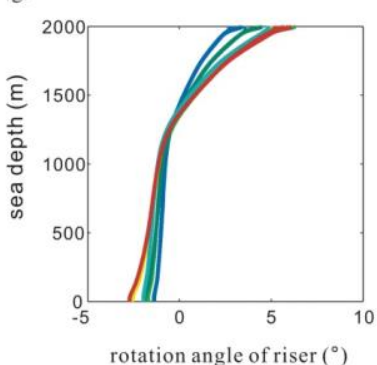

(b)

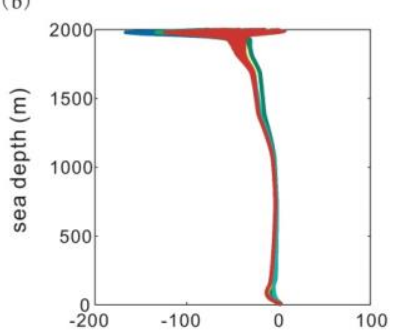

(e)

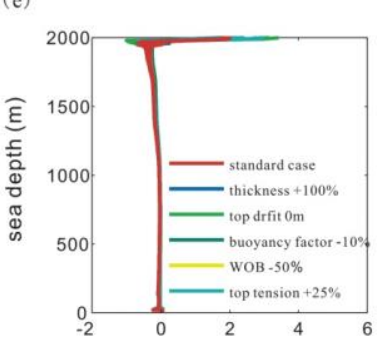

drillstring bending moment $(\mathrm{kN} \cdot \mathrm{m})$

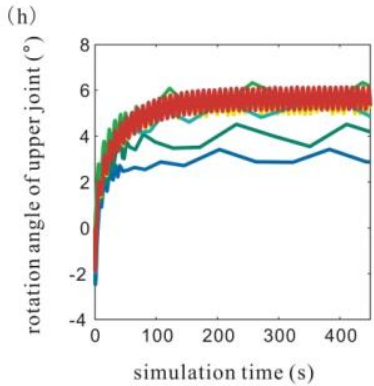

(c)

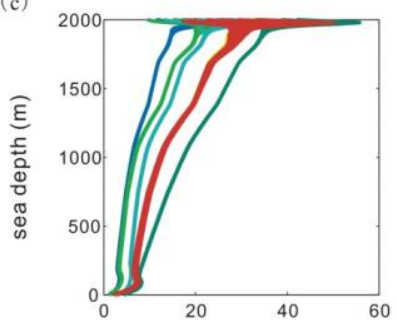

riser Mises stress (MPa)

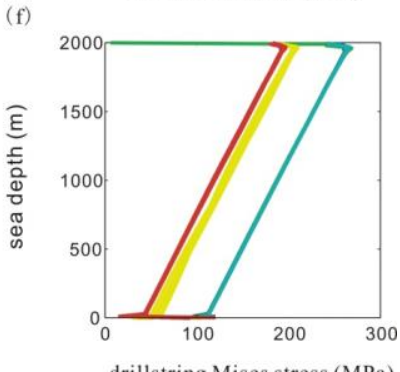

drillstring Mises stress (MPa)

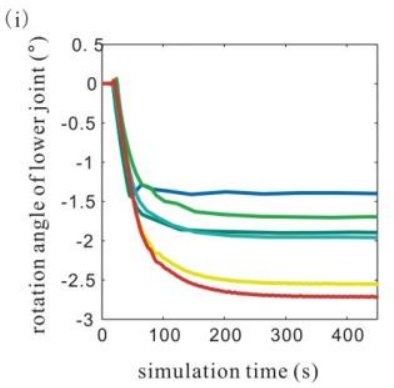

Fig.4. Comparison of dynamic responses of drillstring-riser systems working with different design parameters 
affect the dynamic responses of the drillstring-riser system. Therefore, in order to keep the drillstring-riser system work in a safe condition, the following strategies can be applied, including thickening the riser wall, enhancing the control of the top drift, removing a part of buoyancy modules, decreasing WOB, and increasing the top tension of the riser.

\section{Concluding remarks}

In the presented work, the mathematical model of a drillstring-riser system was developed. The drillstringriser interactions were introduced into the model by a series of spring-friction units along the pipe-in-pipe structure. The drillstring-riser interactions were proved to restrict the system deflection. This finding indicates that, with the same design parameters, a deep water drilling system is capable of working in tougher ocean environment.

The dynamic response of a drillstring-riser system drilling in deep water was obviously different from its response when drilling in shallow water. Specifically, in shallow water, both the bending moment and the Mises stress of the riser varied considerably along the whole system; however, as the sea depth increases to deep levels, the large bending moment and Mises stress were only observed within the top $10 \%$ sea area.

According to the sensitivity analyses of the design parameters, in order to keep the drillstring-riser system work in a safe condition, the operations, such as thickening the riser wall, enhancing the control of the top drift, removing a part of buoyancy modules, decreasing WOB, and increasing the top tension of the riser, were suggested to be applied.

\section{Nomenclature}

\begin{tabular}{|c|c|c|}
\hline$\overline{K_{\mathrm{yY}}}:$ factor of wind speed & $v_{1 W}:$ wind speed $(\mathrm{m} / \mathrm{s})$ & $v_{\mathrm{t}}:$ current speed $(\mathrm{m} / \mathrm{s})$ \\
\hline$z:$ distance from mud line $(\mathrm{m})$ & $L:$ water depth $(\mathrm{m})$ & $\varphi$ : geographic latitude $\left(^{(}\right)$ \\
\hline$h_{y}:$ amplitude of sea wave $(\mathrm{m})$ & $T_{w}:$ period of sea wave $(s)$ & $L_{y}:$ sea wave length $(\mathrm{m})$ \\
\hline$\omega:$ circular frequency of sea wave $(\mathrm{rad} / \mathrm{s})$ & $C_{\mathbb{d}}:$ drag coefficient & $\mathrm{C}_{\mathrm{m}}:$ inertial coefficient \\
\hline$D:$ external diameter of riser $(\mathrm{m})$ & $\rho:$ sea-water density $\left(\mathrm{kg} / \mathrm{m}^{\mathrm{a}}\right)$ & EI: flexural stiffness of riser $\left(\mathrm{N}-\mathrm{m}^{2}\right)$ \\
\hline m: mass of riser per unit length (kg) & $B_{f}$ : buoyancy factor & $P$ : tension of riser $(\mathrm{N})$ \\
\hline$E I^{i}$ : flexural stiffness of drillstring $\left(\mathrm{N}-\mathrm{m}^{2}\right)$ & $P^{\prime}:$ tension of drillstring $(\mathrm{N})$ & $g:$ gravitational acceleration $\left(\mathrm{m} / \mathrm{s}^{2}\right)$ \\
\hline$m^{n}:$ mass of drillstring per unit length (kg) & $K:$ contact stiffness $(\mathrm{N} / \mathrm{m})$ & $\mu$ : friction coefficient \\
\hline$S:$ top drift of riser $(\mathrm{m})$ & A: amplitude of drillbit (m) & $\Omega:$ frequency of drillbit (rad/s) \\
\hline $\begin{array}{l}k_{b}: \text { rotational stiffness of the bottom flexible } \\
\text { joint }(\mathbb{N}-\mathrm{m} / \mathrm{rad})\end{array}$ & $\begin{array}{l}k_{\mathrm{t}}: \text { rotational stiffness of the top } \\
\text { flexible joint }(\mathrm{N}-\mathrm{m} / \mathrm{rad})\end{array}$ & $\begin{array}{l}\text { G: initial gap between riser and } \\
\text { drillstring }(\mathrm{m})\end{array}$ \\
\hline
\end{tabular}

\section{References}

[1] W. Jiang, Deepwater Drilling and Completion Technology: Theory and Practice [M]. Beijing: Petroleum Industry Press, 2015.

[2] S. Zhou, Q. Liu. Theory and Application Research of Deepwater Drilling Riser System Mechanical Behavior [M]. Beijing: Petroleum Industry Press, 2016.

[3] B.G. Burke, An Analysis of Marine Risers For Deep Water [C]. In Offshore Technology Conference, Houston, Texas, USA, 1973.

[4] D.G. Simmonds, Dynamic Analysis Of The Marine Riser [C]. In Society of Petroleum Engineers, Aberdeen, Scotland, UK, 1980.

[5] L.P. Krolikowski, T.A. Gay, An Improved Linearization Technique For Frequency Domain Riser Analysis [C]. In Offshore Technology Conference, Houston, Texas, USA, 1980.

[6] D.W. Dareing, T. Huang, Natural Frequencies of Marine Drilling Risers [J]. Journal of Petroleum Technology, 1976,28(7):813818.

[7] C.L. Kirk, E.U. Etok, M.T. Cooper, Dynamic and Static Analysis of a Marine Riser [J]. Applied Ocean Research, 1979, 1(3):125135.

[8] M.H. Patel, S. Sarohia, K.F. Ng, Finite-Element Analysis of the Marine Riser [J]. Engineering Structures, 1984, 6:175-184.

[9] R.C.S. Bueno, C.K. Morooka, Analysis Method for Contact Forces Between Drillstring-Well-Riser [C]. In International Petroleum Conference and Exhibition of Mexico, Veracruz, Mexico, 1994.

[10] M. Yazdchi, M.A. Crisfeld, Nonlinear Dynamic Behaviour of Flexible Marine Pipes and Risers [J]. International Journal for Numerical Methods in Engineering, 2002, 54:1265-1308.

[11] W.R. Nair, R.E. Baddour, Three-Dimensional Dynamics of a Flexible Marine Riser Undergoing Large Elastic Deformations [J]. Multibody System Dynamics, 2003, 10:393-423.

[12] Chang Y, Chen G, Xu L, et al. Influential Factors for the Design of Ultra-Deepwater Drilling Risers [J]. Petroleum Exploration and Development, 2009, 36(4):523-528.

[13] Y. Wang, D. Gao, J. Fang, Coupled Dynamic Analysis of Deepwater Drilling Riser under Combined Forcing and Parametric Excitation [J]. Journal of Natural Gas Science and Engineering, 27:1739-1747, 2015.

[14] Y. Wang, D. Gao, J. Fang, Optimization Analysis of the Riser Top Tension Force in Deepwater Drilling: Aiming at the Minimum Variance of Lower Flexible Joint Deflection Angle [J]. Journal of Petroleum Science and Engineering, 146:149-157, 2016.

[15] S. Zhou, Q. Liu, W. Jiang, et al. The Discovery of One Third Effect for Deep Water Drilling Riser: based on the Theoretical and Experimental Study of Deformation Characteristics of Deep Water Drilling Riser by Ocean Currents [J]. China Offshore Oil \& Gas, 2013, 25(6):1-7. 
[16] L. Mao, Q. Liu, S. Zhou, et al. Deep Water Drilling Riser Mechanical Behavior Analysis Considering Actual Riser String Configuration [J]. Journal of Natural Gas Science and Engineering, 2016, 33:240-254. 